\title{
Analysis of Consistency in Planning and Budgeting: The Case in Purbalingga Regency
}

\author{
Bayu Kharisma ${ }^{1}$, Sutyastie S. Remi ${ }^{2}$, Alfian Massagony ${ }^{3}$, Al Fitra Ramadhan ${ }^{4}$ \\ ${ }^{1}$ Department of Economics, Universitas Padjadjaran, bayu.kharisma@unpad.ac.id \\ ${ }^{2}$ Department of Economics, Universitas Padjadjaran, tatiremi@gmail.com \\ ${ }^{3}$ Finance and Development Supervisory Agency, alfian19001@mail.unpad.ac.id \\ ${ }^{4}$ Finance and Development Supervisory Agency, fitra19001@mail.unpad.ac.id
}

\begin{abstract}
Consistency of planning and budgeting plays an important role in supporting the government to achieve its strategic objectives and is an important instrument to improve the quality of human development and the welfare of the community. Infrastructure development will open economic access and accelerate the added value of the people's economy. Purbalingga Regional Government through its planning document sets out a development plan to improve infrastructure in the region. The purpose of this research is to analyze the consistency between planning and budgeting in Purbalingga Local Government. The results showed that in general the level of consistency between planning and regional budgeting is relatively good, but the results obtained can not be separated from various shortcomings, where there are still many activities that are not aligned. Some of the things that can be done by the government are increasing the capacity of the team planning apparatus, increasing the role of the regional inspectorate, and increasing the government's commitment in maintaining consistency of planning and budgeting.
\end{abstract}

Keywords: planning, budgeting, consistency, infrastructure

Accepted : 09-11-2020, Revision: 05-02-2020, Published: 01-04-2020

\section{INTRODUCTION}

Planning has an essential role to achieve the goals of development. In carrying out development, every government requires accurate planning and is expected to be able to evaluate the development it does. Karianga (2016) mentioned that as a stability tool of local development, the local budget should be managed to increase the people's welfare. The importance of planning is not only to meet the wishes of the community that is unlimited with limited resources, but also planning is an important indicator for assessing government performance, especially related to its consistency with budgeting. The consistency between planning and budgeting is expected that all government programs and activities can be implemented effectively and efficiently in order to achieve the vision, missions, goals, objectives and policies that have been planned in the planning documents of government. Khusaini, (2014) stated that the inconsistency between planning and budgeting resulted in low absorption of the budget, hence, can hamper regional development.
Infrastructure, besides health and education, has a very important role in fulfilling people's basic rights such as food, clothing, shelter, security, education and health. In addition, infrastructure also plays a role in sustaining national economic growth and global competitiveness. This is in line with the findings from Fox (2007) and Sahin, Can, \& Demirbas (2014) that infrastructure encourages the development of the economy so that poor infrastructure could be one of the main obstacles in economic development.

As an office that has responsibility for the development and maintenance of regional infrastructure, the Public Works and Spatial Planning Agency (Dinas Pekerjaan Umum dan Penataan Ruang, DPUPR) has a significant role to ensure the availability of adequate infrastructure throughout the Purbalingga Regency. The alignment of service planning with the Regent's vision and missions is mandatory, but the other more important thing is proper budgeting in accordance with planned programs and activities. 
This paper tries to analyze the consistency between planning and budgeting in the Purbalingga Regency, specifically in DPUPR, seen through planning documents and Purbalingga Regency budgeting consisting of the 2005-2025 Long-term Regional Development Plan (RPJPD), the 2016-2021 Medium-term Regional Development Plan (RPJMD), the 2018 Regional Work Plan (RKPD), Strategic Plan of DPUPR 2018 (Renstra) and the Budget Implementation Documents (DPA) of DPUPR in 2018.

\section{LITERATURE REVIEW}

Planning is an ongoing process, consisting of decisions or choices of various ways to use existing resources, to achieve specific goals in the future. Kalimullah et al., (2012) state that planning is deciding in advance what is to be done. When a manager plans, he projects a course of action and basing of decisions on purpose, knowledge and considered estimates. Samson (2004) and Taylor (2017) explains that planning is a matter of choosing, and relating to the facts and making and using future assumptions in describing and formulating proposed activities, which is believed necessary to achieve the objectives. While according to the National Development Planning System Law Number 25/2004, planning is a process for determining the right action in the future, through the order of choices, and taking into account available resources.

Budgeting is a series of organizational actions in a relatively short period (usually one year) to determine what targets are to be achieved to achieve organizational goals, what activities must be carried out to achieve these targets, who should carry out these activities and how much resources are needed to support the activities (Mkude et al., 2014). Lee Jr \& Johnson (1998) define budgeting as a mechanism for setting goals and objectives, for allocating the resources necessary to achieve those objectives, for measuring progress toward objectives, for identifying weaknesses or inadequacies in organizations, and for controlling and integrating the diverse activities carried out by numerous subunits within large bureaucracies, both public and private. Mardiasmo (2018) explains that budget is a statement of performance estimation at a particular time and in the form of money, while budgeting is the process or method for preparing the budget. In public sector organizations, budgeting is a political process and must be informed to the public to get input.
The link between planning and budgeting is crucial. Budgeting is an attempt to realize long-term goals by producing the outputs needed to support these long-term goals. It is also a medium for short-term resource allocation, a medium for choosing the right actions, a medium for monitoring and taking responsibility for resource allocation and implementation of shortterm actions. The ultimate achievement of all must be the goals that want to be achieved in the long run. In other words, planning in terms of medium-term and long-term development planning must be in line with the budget in the short-term dimension. Achieving national development goals depends not only on the ability of planners to formulate strategies, actions and policies, but also depends on the ability to allocate resources that will be used efficiently and effectively through government budgets.

Planning and budgeting are the most crucial processes in the administration of government because it is related to the objectives of the government itself for the welfare of the people. Planning and budgeting are an integrated process; therefore, the out put of planning is budgeting. Planning is a strategic guide for realizing the objectives that want to be achieved.

\section{RESEARCH METHOD}

This research tries to analyse the consistency between planning and budgeting in public works and public housing service (DPUPR) Purbalingga Regency, particularly in 2018. The analysis is conducted using descriptive analysis, as the same used by Ramadhiani (2012), with a combination of quantitative approach and qualitative approach. Quantitative approaches that seem more dominant in this research are conducted to find out the level of consistency and level of performance in DPUPR Purbalingga Regency. While in order to explain their relationship and assert the results of quantitative approaches, qualitative approaches are used. The addition of qualitative information is expected to provide additional information that is more useful to explain the results of research

Determination of the consistency between planning and budgeting documents is done by synchronising nomenclature programs and activities using consolidation matrix planning and budgeting, to see how far the level of consistency that occurs and finally is related with the Vision and Mission of Regional Development Plan, and to see how far the consistency of the regional government for realising the vision and mission of regional development. Activities are 
considered consistent if there is mutual related, synchronous or have the same intent and content as the document compared.

The level of consistency based on a percentage as follows (Osrinda \& Delis, 2016)

$\begin{array}{ll}\text { Very bad } & : 0.00-19.9 \\ \text { Bad } & : 20.0-39.9 \\ \text { Average } & : 40.0-59.9 \\ \text { Good } & : 60.0-79.9 \\ \text { Very Good } & : 80.0-100.0\end{array}$

\section{DISCUSSION}

1. Long-term Regional Development Plan and Medium-term Regional Development Plan Consistency Analysis

The long-term regional development plan is a regional development plan for 20 years, which consists of vision, mission, and direction of regional development, and refers to the longterm national development plan. Besides, the medium-term regional development plan is an interpretation of regent's vision, mission, and programs, which is arranged based on the longterm regional development plan and mediumterm national development plan. This document consists of regional financial policy, regional development strategy, public policy and program of regional work department, and cross-regional work department.

According to the Table 1 above, it can be seen that the medium-term regional development plan is already in line with the long-term regional development plan of Purbalingga Regency. Although the number of missions on the medium-term regional development plan is higher than on the long-term regional development plan, the substance of the long-term regional development plan mission is still accommodated on the medium-term regional development plan. 
Table 1. Consolidation Matrix between Long-term and Medium-term Regional Development Plan of Purbalingga Regency

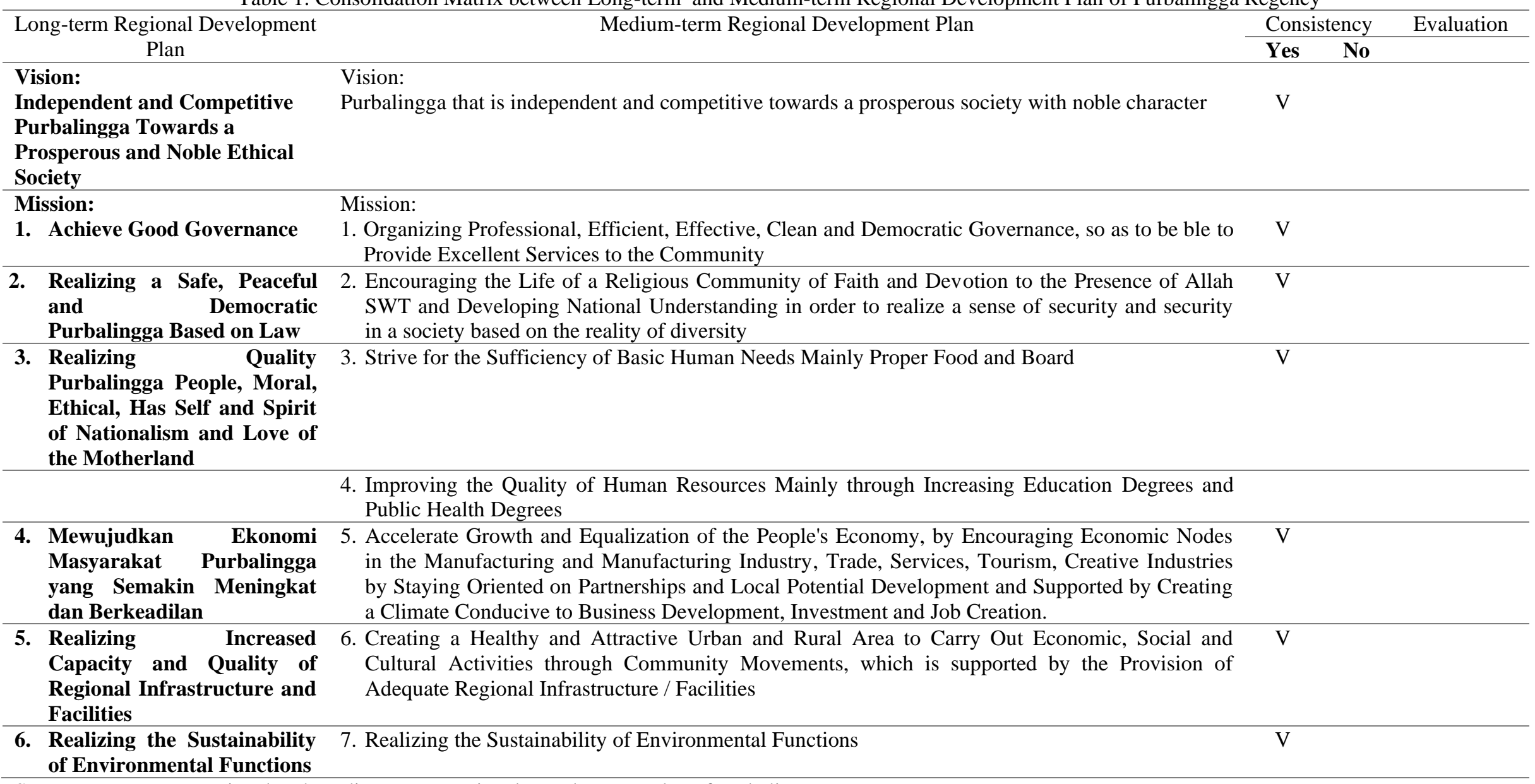

Source: Long-term Regional and Medium-term Regional Development Plan of Purbalingga Regency 
2. Medium-term Regional Development Plan and Regional Work Plan of Purbalingga Regency Consistency Analysis

Even though there is a program whose name differs between the medium-term regional development plan and the regional work plan 2018, overall, the priority programs listed in the mediumterm regional development plan and the regional work plan 2018 have been consistent (see in Table 2).

Table 2. Consolidation Matrix between Medium-term Regional Development Plan and Regional Work Plan of Purbalingga Regency

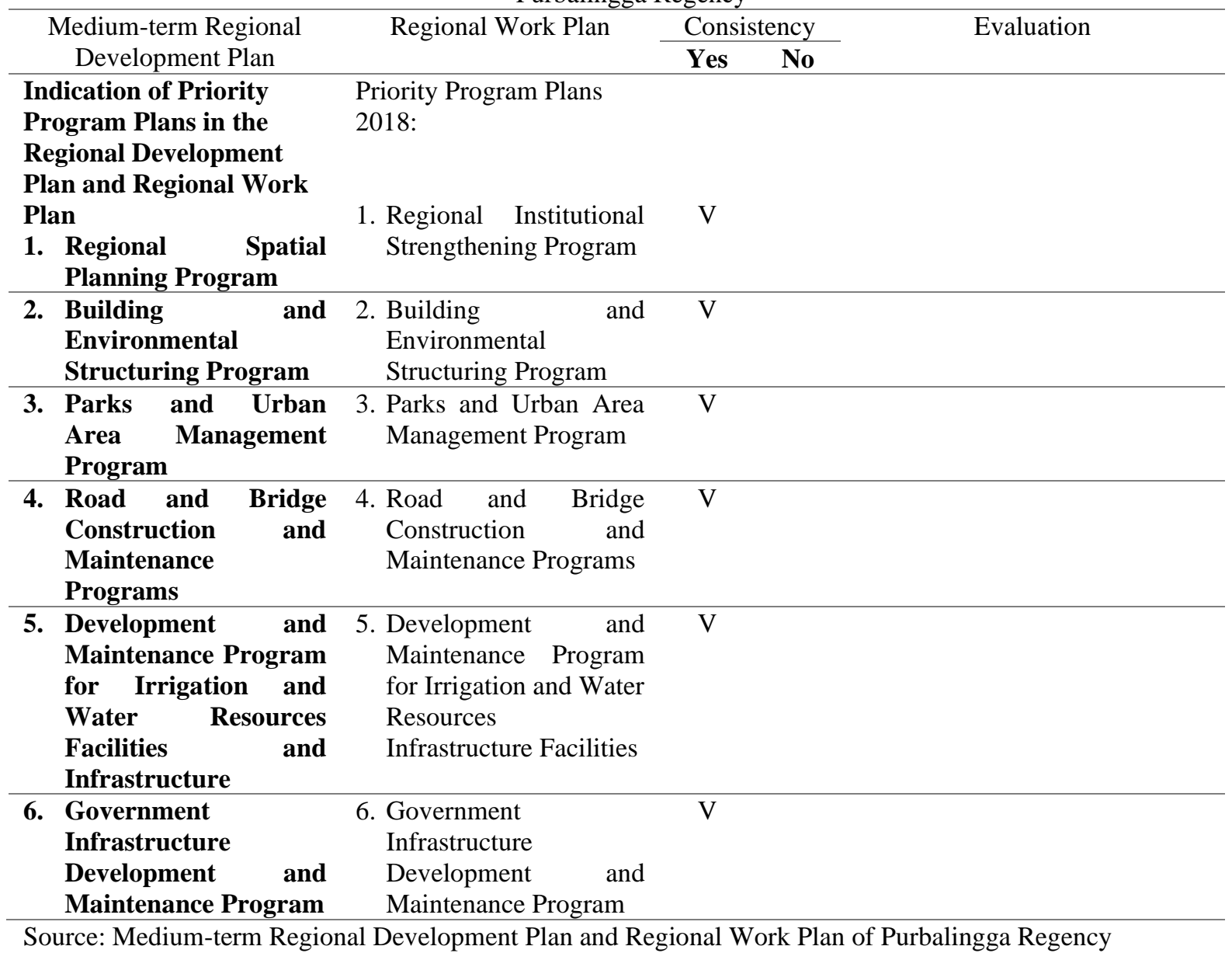


3. Medium-term Regional Development Plan and Strategic Plan of Public Works and Public Housing Service (DPUPR) of Purbalingga Regency Consistency Analysis

Table 3. Consolidation Matrix

between Medium-term Regional Development Plan and Strategic Plan of DPUPR of Purbalingga Regency

\begin{abstract}
Medium-term Regional Development Plan
\end{abstract}

$$
\begin{array}{ll}
\text { Consistency } \\
\text { Yes No }
\end{array}
$$

\section{Vision:}

Purbalingga that is independent and competitive towards a prosperous society with noble character
Vision:

Realization of Services, Infrastructure and Field Services of Public Works that are Solid, Transparent, Efficient and Effective

V

The Vision of Dinas Pekerjaan Umum dan Penataan Ruang is in line with the vision in the medium-term regional development plan, especially in terms of competitive Purbalingga (Purbalingga yang Berdaya Saing) and prosperous Purbalingga (Purbalingga Sejahtera), because it emphasises the role of the organization (Dinas Pekerjaan Umum dan Penataan Ruang) in providing facilities and infrastructure to realise the vision of the medium-term regional development plan.

\section{Mission:}

1. Organizing Professional, Efficient, Effective, Clean and Democratic Governance, so as to be Able to Provide Excellent Services to the Community

2. Encouraging the Life of a Religious Community of Faith and Devotion to the Presence of Allah SWT and Developing National Understanding in order to realize a sense of security and security in a society based on the reality of diversity.

3. Strive for the Sufficiency of Basic Human Needs Mainly Proper Food and Board
Mission:

1. Realizing Professional, Efficient, Effective and Accountable, Transparent, Aspirational, and Sustainable Professional Public Works by Prioritizing Services to the Community

2. Realizing the Condition of Road and Bridge Facilities and Infrastructure that is Steady and Functions to the Maximum Serve the Need for Mobilization of Goods and Passengers in order to Encourage Community Social Economic Activities

3. Realizing the Conditions of Facilities and Infrastructure Health Services Environmental Settlement that is Steady and Decent in Accordance with Spatial and Building Arrangements that are Harmonious, Orderly, Healthy and Safe in Urban Areas as well as in Rural Areas
In general, Dinas Pekerjaan Umum dan Penataan Ruang missions have interpreted the mediumterm regional development plan missions into organisational missions following its area of duties and responsibilities, especially on the sixth and seventh missions. 
4. Improving the Quality of Human Resources Mainly through Increasing Education Degrees and Public Health Degrees

5. Accelerate Growth and Equalization of the People's Economy, by Encouraging Economic Nodes in the Manufacturing and Manufacturing Industry, Trade, Services, Tourism, Creative Industries by Staying Oriented on Partnerships and Local Potential Development and Supported by Creating a Climate Conducive to Business Development, Investment and Job Creation

6. Creating a Healthy and Attractive Urban and Rural Area to Carry Out Economic, Social and Cultural Activities through Community Movements, which is supported by the Provision of Adequate Regional Infrastructure / Facilities

7. Realizing the Sustainability of Environmental Functions

Indication of Priority Program Plans in the Field of

Pekerjaan Umum dan Penataan Ruang:

1. Regional Spatial Planning Program
4. Achieve Solid Water Facilities and Infrastructures that Serve the Maximum Servicing Community Needs for Irrigation Water and Maintaining Smooth and Ordered Water Resources Utilization

5. Realizing Urban Areas, Public Trade Areas, Public Transportation Transit Areas and Public Sports / Entertainment Areas and Park Areas and Orderly, Clean, Cool, Beautiful and Comfortable Urban Forests

\section{Realizing the Implementation,}

Development and Control, Management,

Utilization of Energy and Mineral

Resources, Underground Water, Oil and

Gas, Public Road Lighting and Electricity

Effectively and Efficiently

\section{Building and Environmental Structuring Program}

Priority Program Plans 2018

1. Regional Spatial Use and Control Program

2. Regional Institutional Strengthening
V
This program focuses on maintaining cultural heritage objects whose implementation may be delegated to organisations in charge of cultural affairs. However, related to the provision of legal products regarding the arrangement of buildings and the environment, these activities have been included in the Penataan dan Pengendalian Pemanfaatan Ruang Daerah Program.

3. Parks and Urban Area Management Program

3. Parks and Urban Area Management Program 
4. Road and Bridge Construction and 4. Road and Bridge Construction and V
Maintenance Programs
Maintenance Programs
5. Development and Maintenance Program for 5. Development,
Improvement, $\mathrm{V}$

Irrigation and Water Resources Facilities and Rehabilitation, and Maintenance of

Infrastructure

Irrigation and Irrigation Infrastructure Programs

6. Government Infrastructure Development and 6. Government Infrastructure Capacity and

Maintenance Program Quality Improvement Program

Source : Medium- term Regional Development Plan and Regional Work Plan of Purbalingga Regency 
Overall, the 2016-2021 medium-term regional development plan of Purbalingga Regency and the 2016-2021 DPUPR strategic plan have been consistent, primarily related to the alignment between the vision and mission of the medium-term regional development plan (see in Table 3).

The only difference is found in program priority plans 1 and 2 in the medium-term regional development plan, where program plan 1 in the medium-term regional development plan is interpreted into two program plans in the strategic plan document, and program plan 2 in the mediumterm regional development plan is not included in the priority plan in the strategic plan because some types of activities are included in the Regional Spatial Utilization Arrangement and Control program (Program Penataan dan Pengendalian Pemanfaatan Ruang Daerah) and some others are activities in other organisational fields.

\section{Strategic Plan and Work Plan of DPUPR of Purbalingga Regency Consistency Analysis}

Table 4. Consolidation Matrix between Strategic Plan and Work Plan of public works and public housing service (DPUPR) of Purbalingga Regency

\begin{tabular}{|c|c|c|c|c|}
\hline \multirow[t]{2}{*}{ Strategic Plan Of DPUPR } & \multirow[t]{2}{*}{ Work Plan of DPUPR } & \multicolumn{2}{|c|}{ Consistency } & \multirow[t]{2}{*}{ Evaluation } \\
\hline & & Yes & No & \\
\hline 1 & 2 & $3 \mathbf{a}$ & $3 \mathbf{b}$ & 4 \\
\hline Priority Program Plans 2018 & $\begin{array}{c}\text { Priority Program Plans } \\
2018\end{array}$ & & & \\
\hline $\begin{array}{l}\text { 1.Regional Spatial Use and } \\
\text { Control Program }\end{array}$ & $\begin{array}{l}\text { 1.Regional Spatial Use and } \\
\text { Control Program }\end{array}$ & & $\mathrm{v}$ & $\begin{array}{l}\text { Several activities } \\
\text { are not in line }\end{array}$ \\
\hline $\begin{array}{l}\text { 2. Regional Institutional } \\
\text { Strengthening Program }\end{array}$ & $\begin{array}{l}\text { 2. Regional Institutional } \\
\text { Strengthening Program }\end{array}$ & & $\mathrm{v}$ & $\begin{array}{l}\text { Several activities } \\
\text { are not in line }\end{array}$ \\
\hline $\begin{array}{l}\text { 3. Park and Urban Area } \\
\text { Management Program }\end{array}$ & $\begin{array}{l}\text { 3. Park and Urban Area } \\
\text { Management Program }\end{array}$ & & $\mathrm{v}$ & $\begin{array}{l}\text { Several activities } \\
\text { are not in line }\end{array}$ \\
\hline $\begin{array}{l}\text { 4. Road and Bridge } \\
\text { Construction, Improvement, } \\
\text { Rehabilitation and } \\
\text { Maintenance Programs }\end{array}$ & $\begin{array}{l}\text { 4. Road and Bridge Construction, } \\
\text { Improvement, Rehabilitation and } \\
\text { Maintenance Programs }\end{array}$ & & $\mathrm{v}$ & $\begin{array}{l}\text { Several activities } \\
\text { are not in line }\end{array}$ \\
\hline $\begin{array}{l}\text { 5. Development, } \\
\text { Improvement, } \\
\text { Rehabilitation, and } \\
\text { Maintenance of Irrigation } \\
\text { and Irrigation } \\
\text { Infrastructure Programs }\end{array}$ & $\begin{array}{l}\text { 5. Development, Improvement, } \\
\text { Rehabilitation, and Maintenance } \\
\text { of Irrigation and Irrigation } \\
\text { Infrastructure Programs }\end{array}$ & & $\mathrm{v}$ & $\begin{array}{l}\text { Several activities } \\
\text { are not in line }\end{array}$ \\
\hline $\begin{array}{l}\text { 6. Government } \\
\text { Infrastructure Capacity and } \\
\text { Quality Improvement } \\
\text { Program }\end{array}$ & $\begin{array}{l}\text { 6. Government Infrastructure } \\
\text { Capacity and Quality } \\
\text { Improvement Program }\end{array}$ & & $\mathrm{v}$ & $\begin{array}{l}\text { Several activities } \\
\text { are not in line }\end{array}$ \\
\hline
\end{tabular}

According to the Table 4 above, it can be seen that the preparation of program plans has been consistent, but the preparation of activity plans is still not entirely consistent. Based on the strategic plan document, DPUPR in 2018 has six programs and 120 activities, while based on the 2018 work plan, there are six programs and 202 activities. All programs and activities listed in the strategic plan are accommodated in the work plan document, but there are 82 additional activities from the strategic plan. 


\section{Work Plan of DPUPR Regional Work Plan of Purbalingga Regency Consistency Analysis}

Table 5. Consolidation Matrix between Work Plan of DPUPR Regional Work Plan of Purbalingga Regency

Work Plan of Dinas Pekerjaan Umum Regional Work Plan of Purbalingga Consistency

Evaluation

\begin{tabular}{|c|c|c|c|c|}
\hline & \multirow[b]{2}{*}{ Regency } & \multirow{2}{*}{\multicolumn{2}{|c|}{ Yes No }} & \multirow[b]{3}{*}{4} \\
\hline & & & & \\
\hline 1 & 2 & $\mathbf{3 a}$ & $\mathbf{3 b}$ & \\
\hline Priority Program Plans 2018 & Priority Program Plans 2018 & & & \\
\hline $\begin{array}{l}\text { 1. Regional Institutional } \\
\text { Strengthening Program }\end{array}$ & $\begin{array}{l}\text { 1. Regional Institutional } \\
\text { Strengthening Program }\end{array}$ & $\mathrm{v}$ & & $\begin{array}{l}\text { All activities } \\
\text { are in line }\end{array}$ \\
\hline $\begin{array}{l}\text { 2. Government Infrastructure } \\
\text { Capacity and Quality Improvement } \\
\text { Program }\end{array}$ & $\begin{array}{l}\text { 2. Government Infrastructure } \\
\text { Capacity and Quality Improvement } \\
\text { Program }\end{array}$ & & $\mathrm{v}$ & $\begin{array}{l}\text { Several } \\
\text { activities are } \\
\text { not in line }\end{array}$ \\
\hline $\begin{array}{l}\text { 3. Road and Bridge Rehabilitation } \\
\text { and Maintenance and Development } \\
\text { Program }\end{array}$ & $\begin{array}{l}\text { 3. Road and Bridge Rehabilitation } \\
\text { and Maintenance and Development } \\
\text { Program }\end{array}$ & & $\mathrm{v}$ & $\begin{array}{l}\text { Several } \\
\text { activities are } \\
\text { not in line }\end{array}$ \\
\hline $\begin{array}{l}\text { 4. Program for Development, } \\
\text { Improvement, Rehabilitation, } \\
\text { Maintenance of Facilities and } \\
\text { Irrigation Infrastructure }\end{array}$ & $\begin{array}{l}\text { 4. Water Resources and Irrigation } \\
\text { Infrastructure Development and } \\
\text { Maintenance Program }\end{array}$ & & $\mathrm{v}$ & $\begin{array}{l}\text { Several } \\
\text { activities are } \\
\text { not in line }\end{array}$ \\
\hline $\begin{array}{l}\text { 5. Parks and urban area } \\
\text { management program }\end{array}$ & $\begin{array}{l}\text { 5. Parks and urban area management } \\
\text { program }\end{array}$ & & $\mathrm{v}$ & $\begin{array}{l}\text { Several } \\
\text { activities are } \\
\text { not in line }\end{array}$ \\
\hline $\begin{array}{l}\text { 6. regional spatial planning and } \\
\text { control program }\end{array}$ & $\begin{array}{l}\text { 6. building and environmental } \\
\text { structuring program }\end{array}$ & & $\mathrm{v}$ & $\begin{array}{l}\text { Several } \\
\text { activities are } \\
\text { not in line }\end{array}$ \\
\hline
\end{tabular}

Source : Public Works And Public Housing Service (Dinas Pekerjaan Umum Dan Tata Ruang) Of Purbalingga Regency of Purbalingga Regency

The Table 5 above shows that planning and budgeting process in DPUPR Purbalingga are still inconsistent, as we can see, several activities in the work plan are accommodated on the regional work plan, and vice versa. There are six programs and 202 activities listed on the work plan of DPUPR Purbalingga in 2018. Meanwhile, based on regional work plan document, there are six programs and 203 activities.

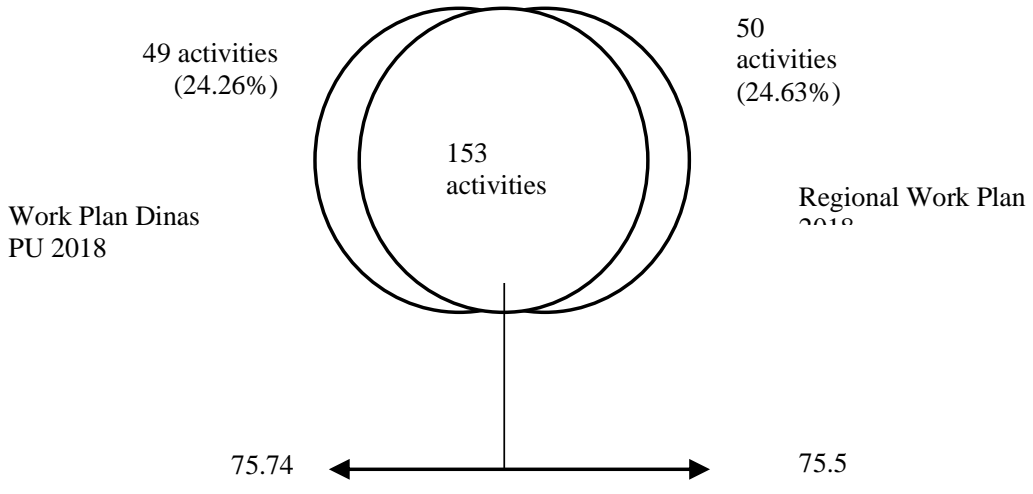

Figure 1. Interrelationship between Work Plan and Regional Work Plan Public Works And Public Housing Service (Dinas Pekerjaan Umum Dan Tata Ruang) of Purbalingga Regency, 2018

From the Figure 1 above, it can be seen that from 202 activities on Work Plan DPUPR and 203 activities on Regional Work Plan 2018, 153 activities are synchronised each other or around $75.45 \%$ activities in Regional Work Plan are accommodated in DPUPR Work Plan, which indicates the consistency is good enough. In contrast, the other 
$24.55 \%$ activities are not consistent with the Regional

Work Plan.

\section{Regional work plan and DPA DPUPR Purbalingga Regency Consistency Analysis.}

Table 6. Consolidation Matrix between Regional Work Plan and the Budget Implementation Documents (DPA) Dinas Pekerjaan Umum dan Penataan Ruang of Purbalingga Regency

\begin{tabular}{|c|c|c|c|c|}
\hline \multirow[t]{2}{*}{$\begin{array}{l}\text { Regional Work Plan Kab. } \\
\text { Purbalingga }\end{array}$} & \multirow[t]{2}{*}{$\begin{array}{l}\text { DPA DPU PR Kab. } \\
\text { Purbalingga }\end{array}$} & \multicolumn{2}{|c|}{$\begin{array}{c}\text { Consistenc } \\
\mathrm{y}\end{array}$} & \multirow[t]{2}{*}{ Evaluation } \\
\hline & & Yes & No & \\
\hline 1 & 2 & $3 \mathbf{a}$ & $\mathbf{3 b}$ & 4 \\
\hline $\begin{array}{l}\text { 1.Regional Institutional } \\
\text { Strengthening Program }\end{array}$ & $\begin{array}{l}\text { 1.Regional Institutional } \\
\text { Strengthening Program }\end{array}$ & $\mathrm{v}$ & & $\begin{array}{l}\text { All activities are in } \\
\text { line }\end{array}$ \\
\hline $\begin{array}{l}\text { 2. Government Infrastructure } \\
\text { Capacity and Quality } \\
\text { Improvement Program }\end{array}$ & $\begin{array}{l}\text { 2. Government Infrastructure } \\
\text { Capacity and Quality } \\
\text { Improvement Program }\end{array}$ & & $\mathrm{v}$ & $\begin{array}{l}\text { Several activities are } \\
\text { not in line }\end{array}$ \\
\hline $\begin{array}{l}\text { 3. Road and Bridge } \\
\text { Rehabilitation and Maintenance } \\
\text { and Development Program }\end{array}$ & $\begin{array}{l}\text { 3. Road and Bridge } \\
\text { Rehabilitation and Maintenance } \\
\text { and Development Program }\end{array}$ & & $\mathrm{v}$ & $\begin{array}{l}\text { Several activities are } \\
\text { not in line }\end{array}$ \\
\hline $\begin{array}{l}\text { 4. Water Resources and } \\
\text { Irrigation Infrastructure } \\
\text { Development and Maintenance } \\
\text { Program }\end{array}$ & $\begin{array}{l}\text { 4. Irrigation Infrastructure } \\
\text { Development and Irrigation } \\
\text { Maintenance Program }\end{array}$ & & $\mathrm{v}$ & $\begin{array}{l}\text { Several activities are } \\
\text { not in line }\end{array}$ \\
\hline $\begin{array}{l}\text { 5. Parks and urban area } \\
\text { management program }\end{array}$ & $\begin{array}{l}\text { 5. Parks and urban area } \\
\text { management program }\end{array}$ & & $\mathrm{v}$ & $\begin{array}{l}\text { Several activities are } \\
\text { not in line }\end{array}$ \\
\hline $\begin{array}{l}\text { 6. building and environmental } \\
\text { structuring program }\end{array}$ & $\begin{array}{l}\text { 6. Regional Spatial Use and } \\
\text { Control Program }\end{array}$ & & $\mathrm{v}$ & $\begin{array}{l}\text { Several activities are } \\
\text { not in line }\end{array}$ \\
\hline
\end{tabular}

Source: Public Works And Public Housing Service (Dinas Pekerjaan Umum Dan Tata Ruang) of Purbalingga Regency, 2018

The Table 6 above depicts that planning and budgeting process in DPUPR of Purbalingga Regency is not well consistent, as we can see several activities are still planned and calculated on DPA DPUPR, even though the activities were not listed and accommodated on the regional work plan. There are six programs and 203 activities listed on the Regional Work Plan in 2018. Meanwhile, based on DPA DPUPR document, there are six programs and 119 activities.

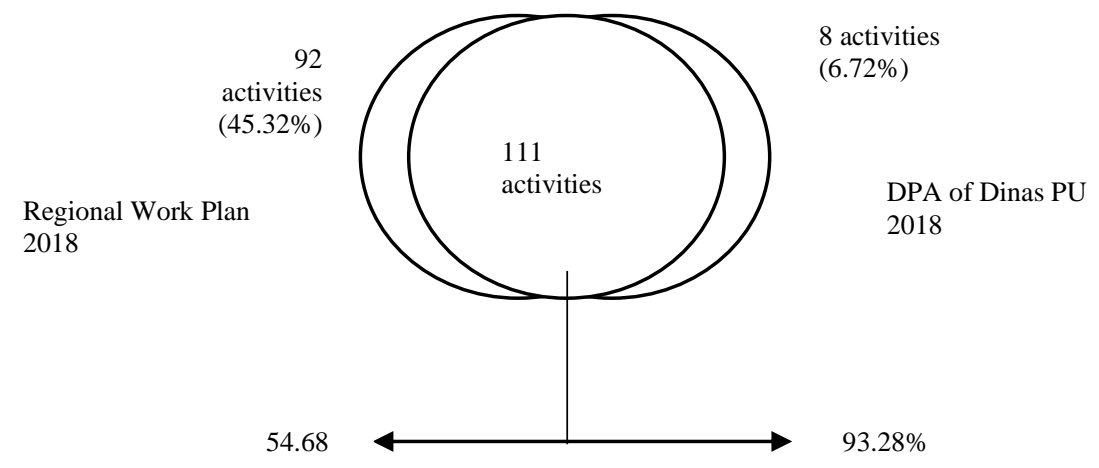

Figure 2. Interrelationship between Work Plan and DPA of Public Works And Public Housing Service (Dinas Pekerjaan Umum Dan Tata Ruang) of Purbalingga Regency, 2018

From the Figure 2 above, it can be seen that from 119 activities on DPA DPUPR and 203 activities in Regional Work Plan 2018, 111 activities are synchronised each other or around $54.68 \%$ activities on Regional Work Plan are accommodated in DPA DPUPR, which indicate the consistency is not good enough. In contrast, the other $45.32 \%$ activities on Regional Work Plan are not listed and served in DPA DPUPR. Meanwhile, the activities in DPA Dinas Pekerjaan Umum and Penataan Ruang 
that are following the Regional Work Plan are around 93.28\%, which shows a high level of consistency. Khusaini (2014) in his study mentioned that the low suitability of programs and activities among documents may be caused by the weak legitimacy of participatory planning.

7. DPA Public Works And Public Housing Service (Dinas Pekerjaan Umum Dan Tata Ruang) and Medium-term Regional Development Plan Consistency Analysis

Table 7. Consolidation Matrix between DPA Public Works And Public Housing Service (Dinas Pekerjaan Umum Dan Tata Ruang) and Medium-term Regional Development Plan

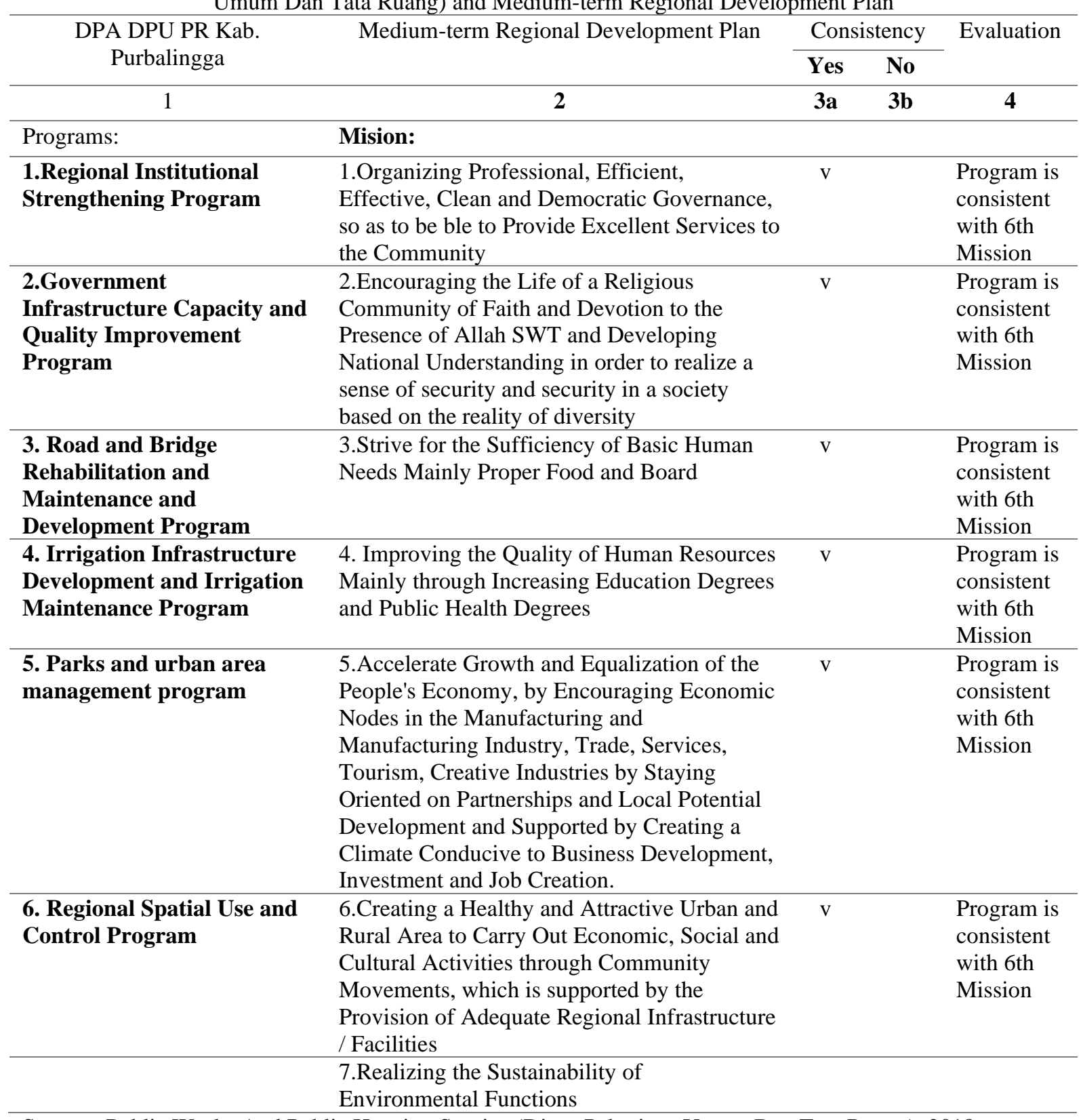

Source : Public Works And Public Housing Service (Dinas Pekerjaan Umum Dan Tata Ruang), 2018

Overall, the 2016-2021 medium-term regional development plan of Purbalingga Regency and the DPA DPUPR have been consistent, primarily the activities in DPA DPUPR are related and focused to the sixth mission of the medium-term regional development plan.

\section{CONCLUSION}

The economy needs reliable infrastructure to connect supply chains and efficiently move goods 
and services. Infrastructure also support the community chance to acquire higher living standard, higher quality healthcare and education. Then, Purbalingga Regional Government through its planning documents sets development plan to improve their infrastructure in order to increase the community welfare. In general, the results of analysis indicate that the level of consistency between planning and budgeting is ranging from average to very good. However, however the results are not flawless, there are still many activities that are not

\section{REFERENCES}

Fitry, R. (2012). Analisis Konsistensi Perencanaan Dan Penganggaran Bidang Kesehatan Kota Lubuklinggau Tahun 2010.

Fox, K. J. (2007). Public Expenditure and Economic Performance: Infrastructure and Productivity.

Kalimullah, N. A., Alam, K., \& Nour, M. (2012). New Public Management: Emergence and Principles. BUP Journal.

Karianga, H. (2016). New Paradigm for Local Financial Management: A Review of Local Budgeting System. Hasanuddin Law Review, 2(3), 398. https://doi.org/10.20956/halrev.v2i3.700

Khusaini, M. (2014). Local government planning and budgeting process: A case of districts and cities in Indonesia. International Journal of Economic Policy in Emerging Economies. https://doi.org/10.1504/IJEPEE.2014.063190

Koontz, H., \& O’Donnell, C. (1972). Principles of Management: Analysis of Managerial Functions.

Lee Jr, R. D., \& Johnson, R. W. (1998). Public Budgeting System.

Mardiasmo. (2009). Akuntansi Sektor Publik. Yogyakarta: ANDI.

Mkude, C. G., Pérez-Espés, C., \& Wimmer, M. A. (2014). Participatory budgeting: A framework to analyze the value-add of citizen participation. Proceedings of the Annual Hawaii International Conference on System Sciences. https://doi.org/10.1109/HICSS.2014.260

Osrinda, N., \& Delis, A. (2016). Analisis Konsistensi Perencanaan dan Penganggaran serta Implikasinya terhadap Capaian Target Kinerja aligned. In response to Purbalingga's Regional Government strategic goal, several measures can be taken by the government. First, the government of Purbalingga should improve quality of team planning officer in making every proposed activity. Second, enhance the role of regional inspectorates in overseeing the planning and budgeting process. Last but not least, the government should increase commitment in maintaining consistency in planning and budgeting.

pada Badan Perencanaan Pembangunan Daerah Kabupaten Merangin. Jurnal Perspektif Pembiayaan Dan Pembangunan Daerah.

Sahin, O., Can, N., \& Demirbas, E. (2014). The Effects of Infrastructure Determinants on Economic Growth: European Union Sample. Eurasian Journal of Business and Economics, 7(13), 11-27.

Samson, D. M. (2004). Principles of management. In Multiple Myeloma and Related Disorders. https://doi.org/10.7748/en.13.1.6.s9

Taylor, F. W. (2017). The Principles of Scientific Management. In Modern Economic ClassicsEvaluations Through Time. https://doi.org/10.4324/9781315270548-22

\section{DATA PENULIS}

Bayu Kharisma adalah Dosen Departemen Ilmu Ekonomi Fakultas Ekonomi dan Bisnis Universitas Padjadjaran Bandung. Menyelesaikan Strata 3 di UGM Jogjakarta, mempunyai ketertarikan penelitian bidang Ekonomi Pembangunan

Sutyastie S. Remi adalah Profesor dalam bidang Ilmu Ekonomi Fakultas Ekonomi dan Bisnis Universitas Padjadjaran Bandung. Menyelesaikan Strata 3 di Universitas Padjadjaran Bandung, mempunyai ketertarikan penelitian bidang Ekonomi Pembangunan

Alfian Massagony. Saat ini bekerja di Badan Pengawas Keuangan dan Pembangunan (BPKP) Bandung, Jawa Barat

Ricky Abdillah. Saat ini bekerja di Badan Pengawas Keuangan dan Pembangunan (BPKP) Bandung, Jawa Barat 